\title{
Ultrahigh bacterial production in a eutrophic subtropical Australian river: Does viral lysis short-circuit the microbial loop?
}

\author{
Peter C. Pollarda,* and Hugh Ducklowb \\ a Australian Rivers Institute, Griffith University, Nathan Campus, Queensland, Australia \\ b The Ecosystems Center, Marine Biological Laboratory, Woods Hole, Massachusetts
}

\begin{abstract}
We studied trophic dynamics in a warm eutrophic subtropical river (Bremer River, Australia) to determine potential sources of dissolved organic carbon (DOC) and the fate of heterotrophic bacterial production. Sustained high rates of bacterial production suggested that the exogenous DOC was accessible (labile). Bacterial specific growth rates $\left(0.2 \mathrm{~h}^{-1}\right.$ to $\left.1.8 \mathrm{~h}^{-1}\right)$ were some of the highest measured for natural aquatic ecosystems, which is consistent with high respiration rates. Bacteria consumed 10 times more organic carbon than that supplied by the daily algal production, a result that implies that terrestrial sources of organic carbon were driving the high rates of bacterial production. Viruses $\left(10^{11} \mathrm{~L}^{-1}\right)$ were 10 times more abundant than bacteria; the viral to bacterial ratio ranged from 3.5 to 12 in the wet summer and 11 to 35 in the dry spring weather typical of eutrophic environments. Through a combination of high bacterial respiration and phage lysis, a continuous supply of terrestrial DOC was lost from the aquatic ecosystem in a $\mathrm{CO}_{2}$-vented bacterial-viral loop. Bacterial processing of DOC in subtropical rivers may be contributing disproportionately large amounts of $\mathrm{CO}_{2}$ to the global carbon cycle compared to temperate freshwater ecosystems.
\end{abstract}

In freshwater ecosystems, bacterial activity respires terrestrial dissolved organic carbon (DOC) and returns $\mathrm{CO}_{2}$ to the atmosphere (Cole and Caraco 2001; Cole et al. 2006; Farjalla et al. 2009a). However, there are few reports that consider the quantitative significance of bacterial dynamics in lakes and rivers as major sources of $\mathrm{CO}_{2}$ to the atmosphere (Richey et al. 2002; Mayorga et al. 2005; Cole et al. 2007).

The interaction of catchment and hydrological processes that supply DOC to rivers regulates microbial structure and metabolism (Sinsabaugh and Findlay 2003). Declines in DOC concentrations along flowing rivers parallel the declines in heterotrophic bacterial activity and dissolved oxygen. These declines are a function of dilution, residence time, and the supply of DOC; and they are linked to variations in microbial metabolism, at least in temperate studies (Sobczak and Findlay 2002). Terrestrial DOC entering an aquatic freshwater ecosystem can be rapidly respired, with most of the water column respiration associated with aerobic heterotrophic bacterial metabolism (Findlay et al. 1998) even if the DOC has persisted in the terrestrial environment for many years (Cole and Caraco 2001). As the DOC moves downstream it supports bacterial respiration, growth, and production, connecting the river with a reservoir of DOC and generating $\mathrm{CO}_{2}$ to become an active part of the global carbon cycle (Cole et al. 2007). Much of the terrestrial DOC derived from the catchment that enters freshwater rivers is respired before it reaches the ocean (Cole and Caraco 2001; Muylaert et al. 2005).

Several factors complicate this picture of catchment to river to ocean carbon flow. $\mathrm{CO}_{2}$ in freshwater can also originate from soil microbial respiration of plant organic carbon (Johnson et al. 2008) and subsequent infiltration. Viruses may also indirectly enhance the use of DOC as a

\footnotetext{
*Corresponding author: p.pollard@griffith.edu.au
}

substrate for bacterial respiration and production (Pollard 2007; Bonilla-Findji et al. 2008; Rohwer and Thurber 2009).

Descriptions of global trends in carbon oxidation are biased toward temperate aquatic environment studies. Even in a major review of freshwater global carbon budgets, conclusions were based primarily on studies of temperate aquatic environments (Sobek et al. 2005, 2007). With less than $3 \%$ of studies carried out in tropical environments, global generalizations are biased toward temperate waters. Partly for these reasons, the DOCbacteria pathway is the biggest gap in our knowledge of the importance of the subtropics in the global carbon cycle (del Giorgio and Cole 2000; del Giorgio and Williams 2005).

The fate of the high bacterial production in subtropical streams is also uncertain. Organic carbon is returned to the DOC pool, with bacterial communities turning over every few days because of viral lysis and/or grazing (Weinbauer et al. 2007; Abedon 2008; Boras et al. 2009). Protozoan bacteriovores were originally thought to provide the link of bacterial production to higher trophic levels (Azam et al. 1983; Sherr and Sherr 1988; Meyer 1994). However, an alternative view suggests that most terrestrially derived DOC is a major subsidy of pelagic bacterial respiration, with little, if any, of this bacterial carbon passing up the food web (Cole et al. 2006). The DOC in estuaries is also a major subsidy of bacterioplankton respiration; again, little of this bacterial production was seen passing up the food web to higher trophic groups (Sobczak et al. 2005). Increasingly, viral infection and lysis of bacteria are viewed as "sinks" of DOC by increasing the amount of DOC that bacteria process (Weinbauer 2004; Suttle 2005; BonillaFindji et al. 2008), thereby preventing bacterial production from passing to higher trophic groups. While freshwater heterotrophic bacteria respire DOC rapidly and efficiently, respiration can be uncoupled from bacterial production 
(Pollard et al. 1997), further diminishing the amount that is transferred to higher trophic groups.

Thus, a recent paradigm shift is emerging that places more emphasis on primary production as the major link to the metazoan production and higher trophic groups in freshwater (Thorp 2002). The major source of this primary production is under debate. On the one hand, riverine food web studies from tropical and arid environments show autochthonous (within the system) algal production as a major source of organic carbon to metazoans (Bunn et al. 2003; Clapcott and Bunn 2003; Bunn et al. 2006), the algae having a high nutritional value (Brett et al. 2009). On the other hand, in temperate environments, allochthonous (outside the system) terrestrial particulate organic carbon is directly subsidizing river and lake food webs via zooplankton (Pace et al. 2004; Cole et al. 2006; Caraco et al. 2010). In either scenario, there is little contribution to higher trophic levels from the heterotrophic bacterial production (Tanaka et al. 2005; Cole et al. 2006; Farjalla et al. 2009b).

We do not know what happens to the high heterotrophic bacterial production in these freshwater ecosystems in which the primary production supports the top-end users. Compared to microbial processes in marine environments and temperate freshwater, little is known about those of subtropical freshwaters, especially the relationship between bacterial production, viruses, and the sources of high $\mathrm{CO}_{2}$ saturation seen in rivers (Marotta et al. 2009).

Globally, partial pressure of $\mathrm{CO}_{2}$ supersaturation, as a consequence of bacterial metabolic activity, is directly correlated with freshwater temperatures (Marotta et al. 2009). With climate change causing increases in global freshwater temperatures (Koeve and Ducklow 2001; Acuna et al. 2008), there is a widening gap in our knowledge of the effect of freshwater bacterial activity in warmer climates. This information is vital to predict future trends in global $\mathrm{CO}_{2}$ budgets, as increases in bacterial production are inversely related to latitude and hence directly related to increasing global temperature. Increases in bacterial activity and changes in its fate could alter the role of rivers in the global carbon cycle, with an increase in the amount of allochthonous DOC that is respired (Acuna et al. 2008). Here, we intend to follow biodegradable DOC inputs into a subtropical river by comparing heterotrophic bacterial production and carbon demand to the rates of primary production, with a view to describing potential pathways for DOC and bacterial production loss from the ecosystem.

\section{Methods}

Location and sampling sites-The Bremer River is a major tributary of the upper Brisbane River, South East Queensland, Australia. The region is characterized by winter and spring dry weather and summer wet weather. The study was carried out in both spring dry and summer wet periods. The Bremer receives runoff from a wide range of land uses such as light and heavy industry, residential, agriculture, grazing, and bush land, and it has been deemed highly eutrophic (Greenwood et al. 1999). The lower reaches are tidally influenced up to $17 \mathrm{~km}$ from the
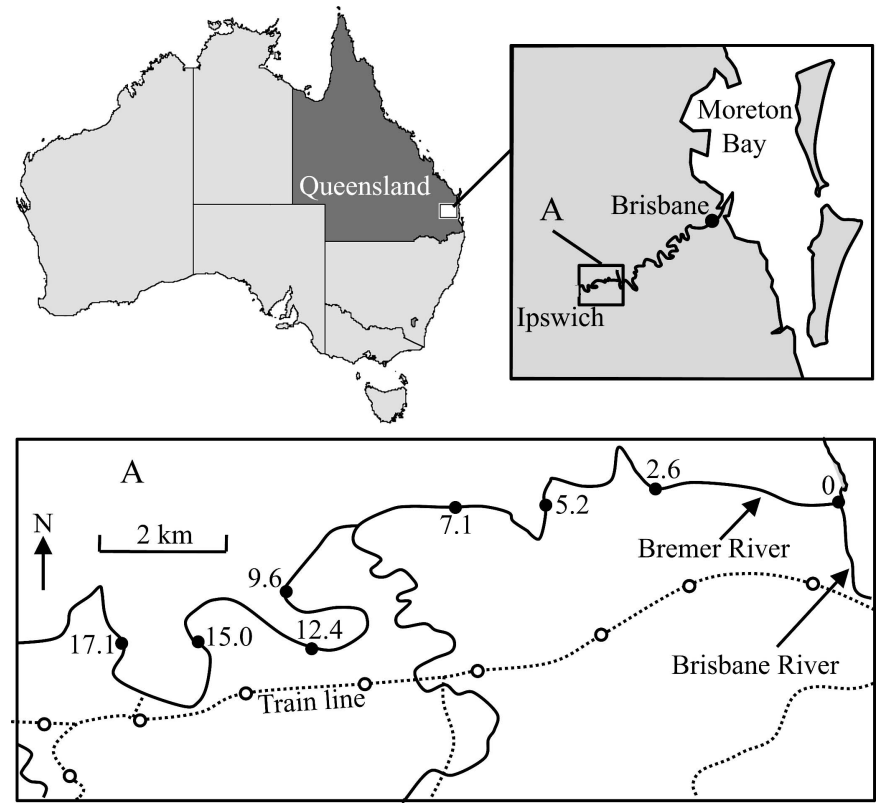

Fig. 1. Bremer River study sites. The eight sites are indicated as the distance $(\mathrm{km})$ from the junction of the Bremer and Brisbane Rivers (AMTD).

junction with the Brisbane River, with little hydrological exchange between them in the dry weather (Pollard et al. 2001). A volume of 3388 ML moves up and down with each tidal cycle; hence it is well aerated and mixed but is minimally exchanged with the Brisbane River downstream. Salinity ranges from $0.13 \mathrm{~g} \mathrm{~L}^{-1}$ to $0.40 \mathrm{~g} \mathrm{~L}^{-1}$ through the year. For much of the time, the freshwater inflows to the river were small in the dry weather. There was little tidal flushing, the water column was well mixed, and there was little exchange with the marine environment (Pollard et al. 2001).

Eight sampling sites (Fig. 1), approximately $2.5 \mathrm{~km}$ apart, were established within the first $17.1 \mathrm{~km}$ at strategic locations - starting at the junction of the Brisbane River (latitude $27^{\circ} 34.946^{\prime}$; longitude $152^{\circ} 51.217^{\prime}$ ). Sampling was 18 September 2000-19 September 2000 in spring dry weather; in summer wet weather it was on 13 February 2001, $12 \mathrm{~d}$ after a major wet weather event in the watershed. For most of the year, the river dry weather physicochemical character persisted; even after rain, it returned to this state within 2 to 3 weeks.

Respiration-A Yellow Springs Instruments 200 biological oxygen demand (BOD) probe (John Morris Scientific) with a built-in stirrer and pretensioned cap membrane was used to measure dissolved oxygen in 300-mL BOD bottles. Bottles were filled with river water and immediately incubated in the dark at ambient temperature for $40 \mathrm{~min}$. The decrease in the dissolved oxygen concentration was used to determine the oxygen uptake rate and the water column respiration rate. The rate of organic carbon respired was calculated from the rate of oxygen used, assuming a respiration quotient of $1: 1$ for $\mathrm{O}_{2}: \mathrm{CO}_{2}$ (del Giorgio and Williams 2005) and that aerobic respiration 
and the bacterial DOM substrates were carbohydrates, proteins, and some nucleic acids.

$D O C$ - An accredited laboratory (Queensland Health and Scientific Services, Coopers Plains, Brisbane, Australia) measured DOC and total organic carbon (TOC) concentrations. Duplicate $100-\mathrm{mL}$ water samples were taken; one was filtered through a prewashed sterile 0.45 $\mu \mathrm{m}$ filter for DOC, while the other was used for TOC analysis. Both were stored in the dark on ice for transport back to the lab, where they were frozen until analyzed.

Primary productivity - Primary productivity was measured using the incorporation of radioactively labeled ${ }^{14} \mathrm{C}$ $\mathrm{HCO}_{3}$. Ranges of light (photosynthetically active radiation [PAR]) intensities were used to establish the relationship between primary productivity and PAR at several sites along the Bremer River. Water was sampled $250 \mathrm{~mm}$ below the surface in the euphotic zone (750 $\mathrm{mm}$ below surface). Shade bags were used to mimic the light profile in the water column. Water samples were added to new $600-\mathrm{mL}$ polycarbonate bottles with $740 \mathrm{MBq}(20 \mu \mathrm{Ci})$ of ${ }^{14} \mathrm{C}$ $\mathrm{HCO}_{3}$ (Millan Panich Biomedical) added in the dark. The incubation was started by mooring the bottle inside the shade bag on the water surface at Cribb Park, Ipswich (Site 15.0 adopted middle thread distance [AMTD]; Fig. 1). To stop the reaction, bottles were placed in the dark on ice $\left(4^{\circ} \mathrm{C}\right)$, and the phytoplankton samples were collected on $47-$ $\mathrm{mm}$-diameter polycarbonate or nylon filters with pore sizes of $0.2,10,20$, or $180 \mu \mathrm{m}$ within $45 \mathrm{~min}$. The filters were acid treated overnight, and the following day scintillant was added and the radioactivity measured. A more detailed description of the method can be found in Pollard and Kogure (1993), with the modification that the natural bicarbonate concentration in the water was determined using the alkalinity, $\mathrm{pH}$, and conductivity in the Bremer River according to Strickland and Parsons (1968). This same paper describes the methanol method used to extract and quantify the chlorophyll $a(\mathrm{Chl} a)$ that was also collected on the filters.

The PAR was measured using a Li-Cor L2000 data logger (Li-Cor). This was fitted with two light sensors; one was an underwater spherical quantum sensor, while the other was a planar quantum sensor used to measure air surface radiance. Both sensors measured light in the wavelength range of 400 to $700 \mathrm{~nm}$. PAR was measured simultaneously at the surface and depth to estimate the percentage transmission.

The relationship between photosynthesis and irradiance (PI function) was described using the model originally described by Eilers and Peeters (1988):

$$
\mathrm{PP}=\mathrm{PAR} \times\left(\mathrm{a} \times \mathrm{PAR}^{2}+\mathrm{b} \times \mathrm{PAR}+\mathrm{c}\right)^{-1}
$$

where PP is the primary productivity, PAR is the photosynthetically active radiation, and $\mathrm{a}, \mathrm{b}$, and $\mathrm{c}$ are the equation parameters.

Primary productivity was determined by integrating the Eilers-Peeters 1988 model for the euphotic zone, over an 8$\mathrm{h}$ day. The latter was based on the daily fluctuating light regime and characteristics of the photosynthesis-light curves of the phytoplankton community.

Bacterial production - In situ heterotrophic bacterial production was determined at all study sites. The rate was directly related to the rate of incorporation of radioactively labeled [methyl- ${ }^{3} \mathrm{H}$ ] thymidine $\left({ }^{3} \mathrm{H}-\mathrm{Tdr}\right)$ into the deoxyribose nucleic acid (DNA) of the dividing bacteria (Fuhrman and Azam 1982) as originally described. This is a filtration followed by an acid washing method that separated the DNA precursor from the labeled DNA.

The ${ }^{3} \mathrm{H}-\mathrm{Tdr}$ was purchased from Millan Panich Biomedical at a concentration of $37 \mathrm{MBq} \mathrm{mL}^{-1}\left(1 \mathrm{mCi} \mathrm{mL}^{-1}\right)$ in sterile aqueous solutions at a specific activity $74 \mathrm{GBq} \mathrm{mmol}{ }^{-1}\left(2 \mathrm{Ci} \mathrm{mmol}^{-1}\right)$. River water was sampled $(15 \mathrm{~mL})$, and the incubation was started immediately by adding $50 \mu \mathrm{L}$ of the stock ${ }^{3} \mathrm{H}-\mathrm{Tdr}\left(1.7 \mu \mathrm{mol} \mathrm{L}^{-1}\right)$. This high concentration was necessary to overcome the abiotic adsorption of the isotope in this rich turbid environment (P. C. Pollard unpubl. data). Each site was sampled and assayed six times $(n=6)$. The assay was stopped with $0.250 \mathrm{~mL}$ of $36 \%(\mathrm{v}: \mathrm{v})$ formaldehyde, and the sample was placed on ice in the dark. Incubation times were to a maximum of $40 \mathrm{~min}$, and a time course was generated for each site as per the isotope dilution study described below. The intercept at time zero represents the control or background label incorporated. The samples were processed in the laboratory within $24 \mathrm{~h}$. No correction to the stock specific activity $\left(2 \mathrm{Ci} \mathrm{mmol}^{-1}\right)$ of thymidine (Tdr) was needed to calculate the bacterial production rates and productivity.

A conversion factor $\left(K_{\mathrm{Tdr}}\right)$ was used to determine the rate of formation of new cells from the rate of incorporation of labeled Tdr ( $\mathrm{r}_{\mathrm{v}, \mathrm{Tdr}}$; Pollard and Greenfield 1997). Similar values for this factor have been derived both empirically and theoretically, and we have used an average value for $K_{\mathrm{Tdr}}$ of $2 \times 10^{18}$ cells mol $\mathrm{Tdr}^{-1}$ (Fuhrman and Azam 1982; Chróst et al. 1988; Bell 1993).

Bacterial and viral abundance-The bacterial and viral abundances at each site were determined using epifluorescence microscopy. For quantifying viral abundance, the bacteria were first removed from the sample on a $0.2-\mu \mathrm{m}$ pore-size filter before the viruses were collected on the aluminum oxide filter. There were so many bacteria that they often obscured the viruses; hence bacteria and viruses were counted on separate filters.

Based on the dominance of bacteria both in abundance and rates of reproduction (populations of $10^{7}$ doubling every $20 \mathrm{~min}$ ) over eukaryotic unicellular organisms, which take days if not weeks to replicate in the pelagic environment, we have assumed that free viruses were mostly bacteriophages (Thingstad et al. 2008; Boras et al. 2009).

Bacteria and viruses were stained with SYBR ${ }^{\circledR}$ Green-1 (Molecular Probes; Noble and Fuhrman 1998). The stock solution of SYBR ${ }^{\circledR}$ Green-1 was diluted $1: 2.5 \times 10^{-3}$ with $0.02-\mu \mathrm{m}$-filtered, Milli-Q deionized water (working solution). The $\mathrm{pH}$ of a $5-\mathrm{mL}$ river water sample was measured and, if below 7, adjusted with Tris-ethylenediaminetetra- 
acetic acid buffer. The SYBR ${ }^{\circledR}$ Green-1 $(30 \mu \mathrm{L})$ working solution was added per $1 \mathrm{~mL}$ of the sample. After $30 \mathrm{~min}$ in the dark, the sample was filtered through a $0.22-\mu \mathrm{m}$-poresize, 25-mm diameter, black polycarbonate membrane filter (Millipore Australia) to collect the bacteria. The filtrate was collected and then filtered through a $0.025-\mu \mathrm{m}$ Whatman, $\mathrm{Al}_{2} \mathrm{O}_{3}$ Anodisc 25 filter (Crown Scientific) on a Millipore manifold at $15 \mathrm{kPa}$ until dry, to collect the viruses.

Filters were transferred to glass slides and covered with a drop of nonfluorescent oil (Cargile B) and a 25-mm coverslip, and another drop was added on top of the coverslip. The bacteria and viruses were counted using an Olympus epifluorescent microscope (model CH30) equipped with a 100/1.25 objective lens and a blue filter set (excitation $<490 \mathrm{~nm}$; dichroic filter, $500 \mathrm{~nm}$; barrier filter, $>515 \mathrm{~nm}$ ). A $100 \times$ oil immersion objective was used with a $10 \times$ ocular that contained a counting graticule. The graticule was calibrated with a $0.1-\mathrm{mm}$ stage micrometer. The numbers of bacteria and viruses in the sample were determined with the graticule in the ocular of the microscope.

Bacterial carbon content-The carbon content of the bacterial cells is an essential parameter for comparing bacterial productivity in trophic studies of aquatic environments (Ducklow 2000). The type of bacteria, its nutrient environment, and its growth state influence the size (volume) and shape of a bacterial cell. Therefore we measured cell volumes of the bacteria in the Bremer River. Cell dimensions were measured on photographs of stained bacteria as von Münch and Pollard (1997) have described.

Bacteria were measured (length [ $\left.\mathrm{L}_{\text {cell }}\right]$ and width [ $\left.\mathrm{W}_{\text {cell }}\right]$ ) in the water sample. The cell volume $\left(\mathrm{V}_{\text {cell }}\right)$ of each bacterium was calculated with the following formula:

$$
\mathrm{V}_{\text {cell }}=\frac{\pi}{4} \times \mathrm{W}_{\text {cell }}^{2} \times\left(\mathrm{L}_{\text {cell }}-\frac{\mathrm{W}_{\text {cell }}}{3}\right)
$$

This formula is based on bacteria that are straight rods with hemispherical ends, but it works equally well for cocci. On average, the bacteria in the Bremer sample had a cell volume of $0.16 \pm 0.02 \mu \mathrm{m}^{3}$, length of $1.0 \pm 0.03 \mu \mathrm{m}$, and width of $0.5 \pm 0.01 \mu \mathrm{m}$ (mean $\pm \mathrm{SE}, n=100$ ).

Using a conservative value for the carbon content per

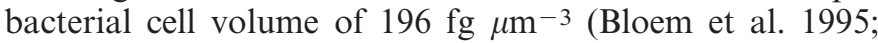
Ducklow 2000) and the cell volume $\left(0.16 \mu \mathrm{m}^{3}\right)$, the bacterial mean biomass in terms of carbon was calculated using $31 \pm 8 \mathrm{fg}$ carbon per bacterial cell. This figure was used to convert the bacterial cell production rates (cells $\mathrm{m}^{-3} \mathrm{~h}^{-1}$ ) into the bacterial carbon productivity $\left(\mu \mathrm{g} \mathrm{C} \mathrm{m}^{-3} \mathrm{~h}^{-1}\right)$.

Bacterial specific growth rates-From the bacterial production and the number of bacteria at each site, the specific growth rates $\mu$ were determined as

$$
\mu=\frac{d x}{d t} \times \frac{1}{\mathrm{X}}=\frac{\mathrm{P}}{\mathrm{X}}
$$

where $\mathrm{X}$ is the concentration of bacteria at time $(t)$ and

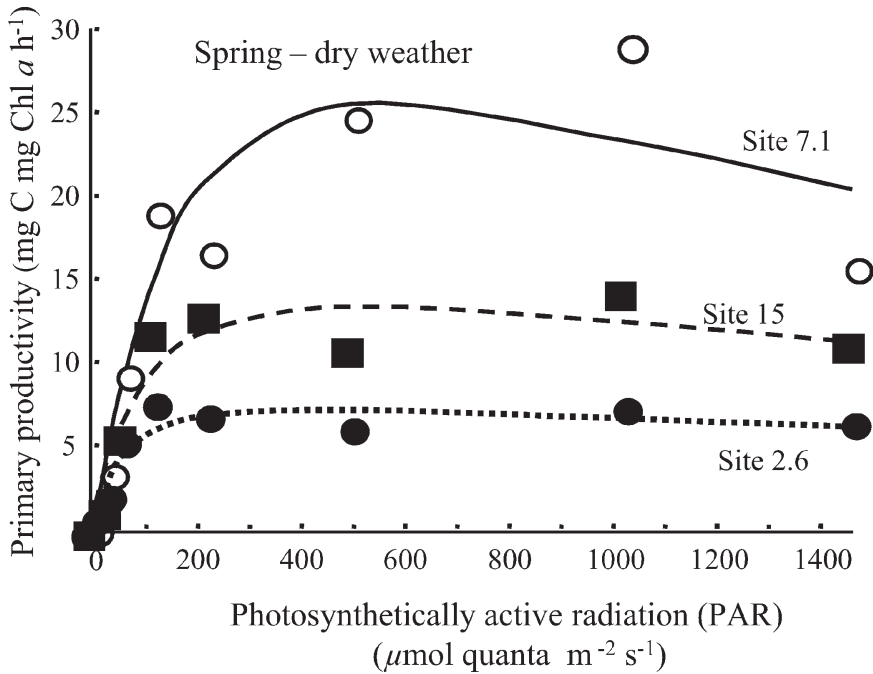

Fig. 2. The relationship between primary production and PAR during spring (dry weather). This relationship was determined for phytoplankton collected on $0.2-\mu \mathrm{m}$-pore-size filters using water samples collected from Sites 2.6, 7.1, and $15.0 \mathrm{~km}$ AMTD (Fig. 1).

bacterial production rate $(\mathrm{P})$ is the rate of increase in the number of bacteria $(d x / d t)$, i.e., the production rate divided by the number of bacteria.

Data analysis-Wet and dry weather data sets were compared by performing $F$-tests, generally with $n=8$. Significance was evaluated at the $p=0.05$ level.

\section{Results}

Primary and secondary production in this ecosystem were measured to determine quantitatively their trophic relevance to each other. The heterotrophic bacterial production was used to determine the bacterial carbon (DOC) demand in combination with respiration measurements.

Primary productivity - The relationships between photosynthesis (primary productivity in terms of carbon) and irradiance (PI function) for Sites 2.6, 7.1, and $15.0 \mathrm{~km}$ are shown in Figs. 2 and 3, with their characteristics summarized in Table 1. For dry weather, the maximum rates of primary productivity were between 7 and $26 \mathrm{mg} \mathrm{C} \mathrm{mg} \mathrm{Chl}$ $a^{-1} \mathrm{~h}^{-1}$ with optimal PAR light intensities of about $500 \mu$ mol quanta $\mathrm{m}^{-2} \mathrm{~s}^{-1}$ (Table 1; Fig. 2). The euphotic zone was determined from the relationship between primary productivity and PAR light and the depth to which PAR penetrated the water column along the river. Most primary productivity was in the top $0.75 \mathrm{~m}$ of the water column. Water samples taken within or below this euphotic zone produced similar PI curve characteristics. This reflected the well-mixed nature of the shallow water column.

Wet weather showed a very different picture of phytoplankton productivity (Fig. 3). Rainfall, $12 \mathrm{~d}$ prior to sampling, and the subsequent increase in turbidity and 


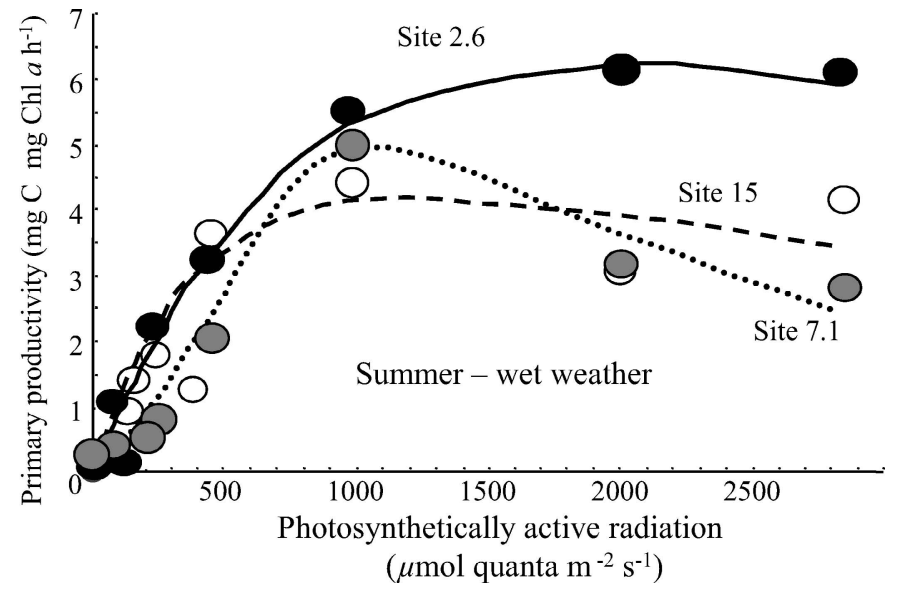

Fig. 3. The relationship between primary productivity and PAR during summer (wet weather). This relationship was determined for phytoplankton collected on $0.2-\mu \mathrm{m}$-pore-size filters using water collected from Sites 2.6, 7.1, and $15.0 \mathrm{~km}$ AMTD (Fig. 1).

DOC in the water column, meant less light was available for photosynthesis. Compared to spring dry weather, primary productivity decreased to 4 and $6 \mathrm{mg} \mathrm{C} \mathrm{mg} \mathrm{Chl}$ $a^{-1} \mathrm{~h}^{-1}$, while optimal light intensities increased to between 1000 and $1900 \mu \mathrm{mol}$ quanta $\mathrm{m}^{-2} \mathrm{~s}^{-1}$ (Table 1; Fig. 3). Photoinhibition occurred at the higher light intensities.

We divided the phytoplankton production into the different size fractions that were responsible for primary production. The nanoplankton $(2-20 \mu \mathrm{m})$ fraction (cyanobacteria and small chlorophyta) was responsible for most of the phytoplankton production in both seasons, but production was 10 times greater in the spring dry weather (Table 2) because the water column was much less turbid.

DOC-More than $90 \%$ of the organic carbon in the river was dissolved (difference between TOC and DOC); the
DOC average was $6.12 \pm 0.44 \mathrm{mg} \mathrm{L}^{-1}($ mean $\pm \mathrm{SE}, n=8)$ in dry weather and $12.59 \pm 0.90 \mathrm{mg} \mathrm{L}^{-1}$ (mean $\pm \mathrm{SE}, n=$ 8 ) in wet weather (Table 2). DOC was significantly different between wet and dry periods $\left(F\right.$-test, $F_{\mathrm{df}}=7, p$ $<0.001)$.

Heterotrophic bacterial production and productivityFigure 4 shows Site 15.0 (midriver; summer dry season) Tdr incorporation with time, using two different concentrations of labeled Tdr. The mean of both slopes was 0.233 \pm 0.015 , which equated to a high bacterial productivity of 960 pmol Tdr $\mathrm{L}^{-1} \mathrm{~h}^{-1}$. Linear kinetics were observed with high correlation coefficients for each concentration of isotope. Slopes were also similar, showing that no isotope dilution occurred, i.e., the rates of isotope incorporation were independent of the concentration used (Pollard and Moriarty 1984). This relationship was reproduced at each study site for dry and wet weather. Tdr incorporation rates were exceptionally high (Table 2). Time course incubations accumulated significant amounts of radioactivity above the zero time control (blanks) after just $5 \mathrm{~min}$ and remained linear for at least 40 min (Fig. 4).

On the other hand, bacterial abundance was not exceptionally high $\left(1-9 \times 10^{9} \mathrm{~L}^{-1}\right.$; Table 2 ; Fig. 5), given the high incorporation rates. The resulting specific growth rates, derived as explained above, were accordingly high (Table 2).

Despite the difference between summer and spring water temperatures $\left(27.3^{\circ} \mathrm{C}\right.$ and $19.1^{\circ} \mathrm{C}$, respectively), there was little difference between the bacterial productivity-91 \pm $8 \mathrm{mg} \mathrm{C} \mathrm{m}^{-3} \mathrm{~h}^{-1}$ in the dry weather compared to $111 \pm$ $17 \mathrm{mg} \mathrm{C} \mathrm{m}^{-3} \mathrm{~h}^{-1}$ (mean $\left.\pm \mathrm{SE}, n=8\right)$ in wet weather $(F$ test, $\left.F_{\mathrm{df}}=7, p<0.04\right)$.

However, there was a twofold increase in the specific growth rates in the summer wet compared to the spring dry season $\left(1.33 \pm 0.32 \mathrm{~h}^{-1}\right.$ summer and $0.69 \pm 0.20 \mathrm{~h}^{-1}$ spring; mean $\pm \mathrm{SE}, n=8$ ), primarily because the

Table 1. Phytoplankton photosynthetic characteristics. Data generated from the primary productivity vs. irradiance relationships (PI curves) for upper, middle, and lower reaches of the Bremer River in spring and summer.

\begin{tabular}{|c|c|c|c|c|c|c|c|}
\hline \multirow{2}{*}{$\begin{array}{c}\text { Primary } \\
\text { production }(\mathrm{PP})^{*}\end{array}$} & \multicolumn{3}{|c|}{ Spring dry weather } & \multicolumn{3}{|c|}{ Summer wet weather } & \multirow[t]{2}{*}{ Remarks } \\
\hline & 2.6 & 7.1 & 15.0 & 2.6 & 7.1 & 15.0 & \\
\hline $\begin{array}{r}\mathrm{P}_{\max }(\mathrm{mg} \mathrm{C} \mathrm{mg} \\
\left.\mathrm{Chl} a^{-1} \mathrm{~h}^{-1}\right)\end{array}$ & 6.9 & 25.5 & 14.2 & 6.2 & 4.2 & 5.1 & $\begin{array}{l}\text { Maximum rate of } \\
\text { production }\end{array}$ \\
\hline $\begin{array}{l}\mathrm{I}_{\mathrm{m}}(\mu \mathrm{mol} \text { quanta } \\
\left.\mathrm{m}^{-2} \mathrm{~s}^{-1}\right)\end{array}$ & 432.6 & 550.1 & 528.0 & 1924.5 & 1199.7 & 1131.0 & Optimal intensity \\
\hline $\begin{array}{l}\mathrm{I}_{\mathrm{k}}(\mu \mathrm{mol} \text { quanta } \\
\left.\mathrm{m}^{-2} \mathrm{~s}^{-1}\right)\end{array}$ & 46.4 & 136.0 & 85.9 & 666.9 & 330.6 & 1395.7 & $\begin{array}{l}\text { Characteristic } \\
\text { intensity }\end{array}$ \\
\hline $\mathrm{S}+$ & 0.149 & 0.188 & 0.165 & 0.009 & 0.013 & 0.004 & Initial slope \\
\hline Photoinhibition & 7.3 & 2.0 & 4.1 & 0.9 & 1.6 & -1.2 & $\begin{array}{l}\text { Relative index of } \\
\text { photoinhibition } \\
\text { potential (smaller } \\
\text { values } \\
\text { correspond to } \\
\text { greater potential) }\end{array}$ \\
\hline
\end{tabular}

\footnotetext{
* Determined from PI function described in Methods.

$\uparrow$ Distance from the junction of the Bremer and Brisbane Rivers.

\$ S units $=\left(\mathrm{mg} \mathrm{C} \mathrm{mg} \mathrm{Chl} a^{-1} \mathrm{~h}^{-1}\right) /\left(\mu \mathrm{mol}\right.$ quanta $\left.\mathrm{m}^{-2} \mathrm{~s}^{-1}\right)$.
} 


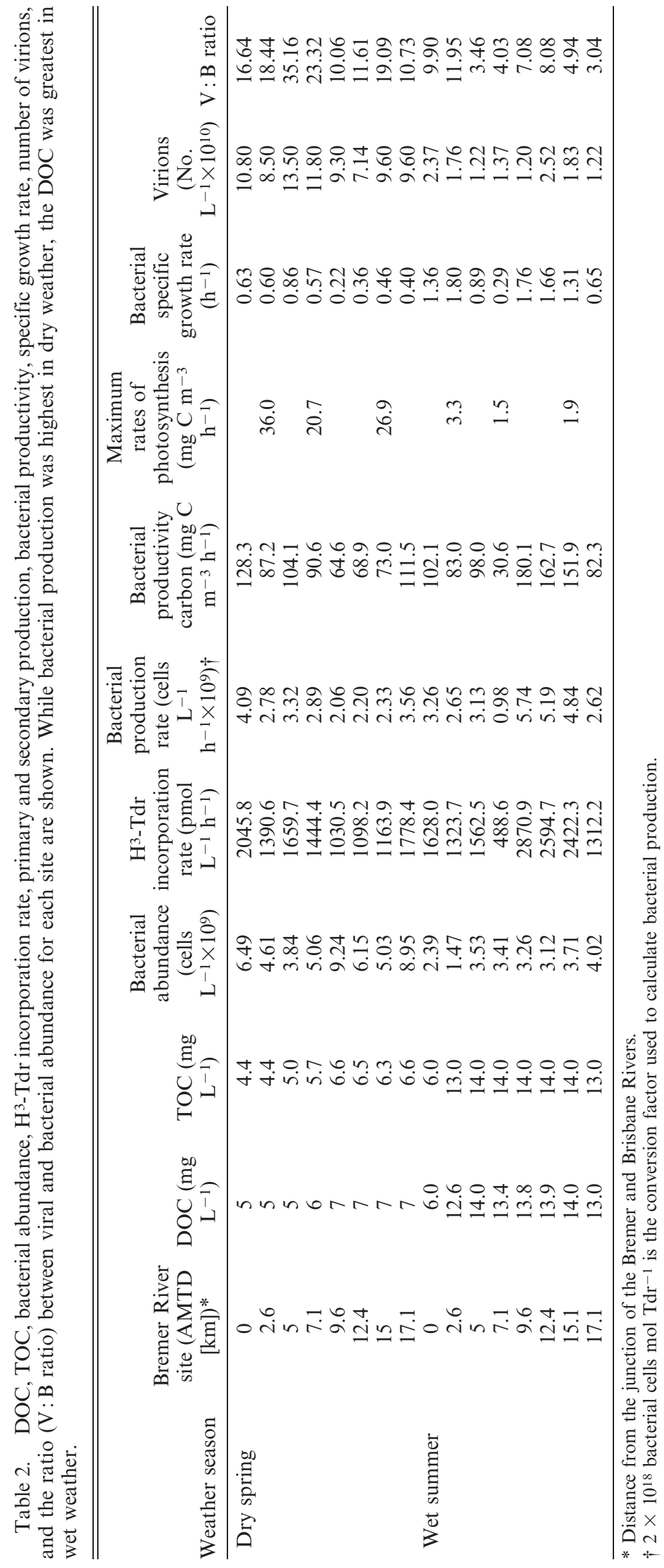




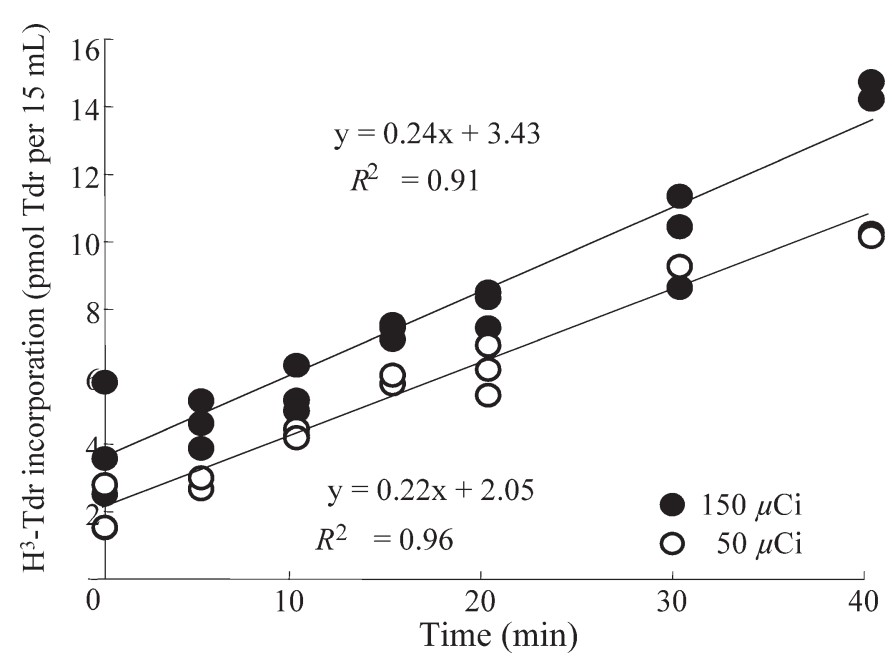

Fig. 4. Typical time course, kinetic, and isotope dilution study of the rate of incorporation of ${ }^{3} \mathrm{H}-\mathrm{Tdr}$ into bacterial DNA. Linear kinetics were observed with high correlation coefficients for each concentration of isotope. This relationship was reproduced at each study site for dry and wet weather. No isotope dilution occurred as the slopes were similar (Pollard and Moriarty 1984; Site 15.0 midriver; dry weather; mean of both slopes was $0.24=960$ pmol Tdr $\left.\mathrm{L}^{-1} \mathrm{~h}^{-1}\right)$.

abundances were lower (Table 2). Specific growth rates were significantly different between wet and dry periods $(F$ test, $F_{\mathrm{df}}=7, p<0.019$ ).

Abundance of bacteria and viruses-The abundance of pelagic bacteria and viruses and the ratio between the two (V: B ratio) can be compared in Table 2 and Fig. 5. The average spring bacterial abundance was twice that of summer-6.20 $\pm 0.70 \times 10^{12}$ cells m$^{-3}$ compared to $3.10 \pm$ $0.34 \times 10^{12}$ cells m ${ }^{-3}($ mean $\pm \mathrm{SE}, n=8)$. Viral abundance was 10 times greater than bacterial abundance. In spring dry weather, the average number of viruses was $10.0 \pm 1.1$ $\times 10^{13}$ virus-like particles (VLPs) $\mathrm{m}^{-3}$ (mean $\pm \mathrm{SE}, n=8$ ), which was significantly higher ( $F$-test, $F_{\mathrm{df}}=7, p<0.001, n$ $=8$ ) than the summer wet weather average of $1.7 \pm 2.5 \times$ $10^{13}$ VLPs $\mathrm{m}^{-3}$ (mean $\pm \mathrm{SE}, n=8$ ).

The association of viral (V) and bacterial (B) abundance can be described with the $\mathrm{V}: \mathrm{B}$ ratio, which was $19.0 \pm 3.5$ (mean $\pm \mathrm{SE}, n=8)$ in the dry and $6.5 \pm 1.1($ mean $\pm \mathrm{SE}, n$ $=8)$ in the wet. The $\mathrm{V}: \mathrm{B}$ ratio was significantly $(p<0.001$, $n=8$ ) higher in spring dry weather compared to the wet summer. Within each season, the trend in $\mathrm{V}: \mathrm{B}$ ratios followed those of bacterial-specific growth rates (Table 2).

\section{Discussion}

Various assumptions are typically made to derive estimates of bacterial production rates (Ducklow 2000). Our assumptions are discussed briefly before exploring the implications of the high production rates for carbon flux in the Bremer River. This study also complements that of Hewson et al. (2001), who determined the VLP distribution in the sediments and water column in the Brisbane River and Moreton Bay $26 \mathrm{~km}$ downstream from the junction of the Bremer and Brisbane Rivers.

Bacterial carbon demand (BCD) is the DOC used as substrate for bacterial metabolism (del Giorgio and Cole 2000). The flows of DOC into bacterial production and respiration are related by the bacterial growth efficiency (BGE) term that is defined as bacterial production/ (bacterial production + bacterial respiration) (Farjalla et al. 2009b). Determining quantitatively the amount of readily degradable DOC supplied to the bacteria relies on sensitive and accurate measurements of bacterial production in situ. We achieved this through the measurement of the incorporation of ${ }^{3} \mathrm{H}-\mathrm{Tdr}$ into growing bacteria after taking into account background (nonspecific binding of the isotope) and isotope dilution. This dilution can be the result of the cell's ability to synthesize its own Tdr residues and must be considered in cases in which ${ }^{3} \mathrm{H}-\mathrm{Tdr}$ is used to measure bacterial growth rates (Pollard and Moriarty 1984).

Isotope dilution-Our kinetic study of the rate of incorporation of ${ }^{3} \mathrm{H}-\mathrm{Tdr}$ into bacterial DNA showed that the rate of incorporation of the radiolabeled $\mathrm{Tdr}$ into bacterial DNA was linear for at least $40 \min \left(r^{2}=0.9\right.$; Fig. 4) for the incubation of $50 \mu \mathrm{Ci}$ and $150 \mu \mathrm{Ci}{ }^{3} \mathrm{H}-\mathrm{Tdr}$, respectively. The rate of incorporation of ${ }^{3} \mathrm{H}-\mathrm{Tdr}$, as indicated by the slopes, was the same irrespective of the concentration of Tdr used. The bacteria were not likely using the Tdr as a carbon source as there were sufficient other sources of DOC (Table 2). The correlation coefficients were close to 1 , and each showed a similar rate of isotope incorporation. Hence we also showed that there was no isotope dilution from the de novo synthesis of Tdr (Pollard and Moriarty 1984). This was the basis for choosing $50 \mu \mathrm{Ci}$ to determine the bacterial production (i.e., final concentration of $\mathrm{Tdr}$ was $1.7 \mu \mathrm{mol} \mathrm{L}^{-1}$ ).

The intercept on the x-axis in Fig. 4 represented the zero time control (background). The high backgrounds were due to the nonspecific binding of ${ }^{3} \mathrm{H}-\mathrm{Tdr}$ to suspended colloidal clay particles in the water column. This same suspended material also caused the low light penetration through the water column in the summer wet weather. In spite of the high zero time background, the highly linear time courses establish the precision of the rate estimates.

Conversion factors - We chose conservative conversion factors to determine bacterial production based on those used in marine and freshwater research (see Methods). The high rates of bacterial production were due to the high rate of incorporation of Tdr and were not due to the conversion factors or artifacts (background labeling was taken into account) in the method used. Bacterial cell volumes for the Bremer were measured directly, and a conservative value for cell carbon content was used to determine productivity. These high rates were further supported by the high rates of bacterial respiration (Table 3 ).

Bacterioplankton production and carbon demand-We reviewed other measurements of bacterial specific growth rates in aquatic systems (Table 4). Generally, bacterial specific growth rates in freshwater were more than 10 times 


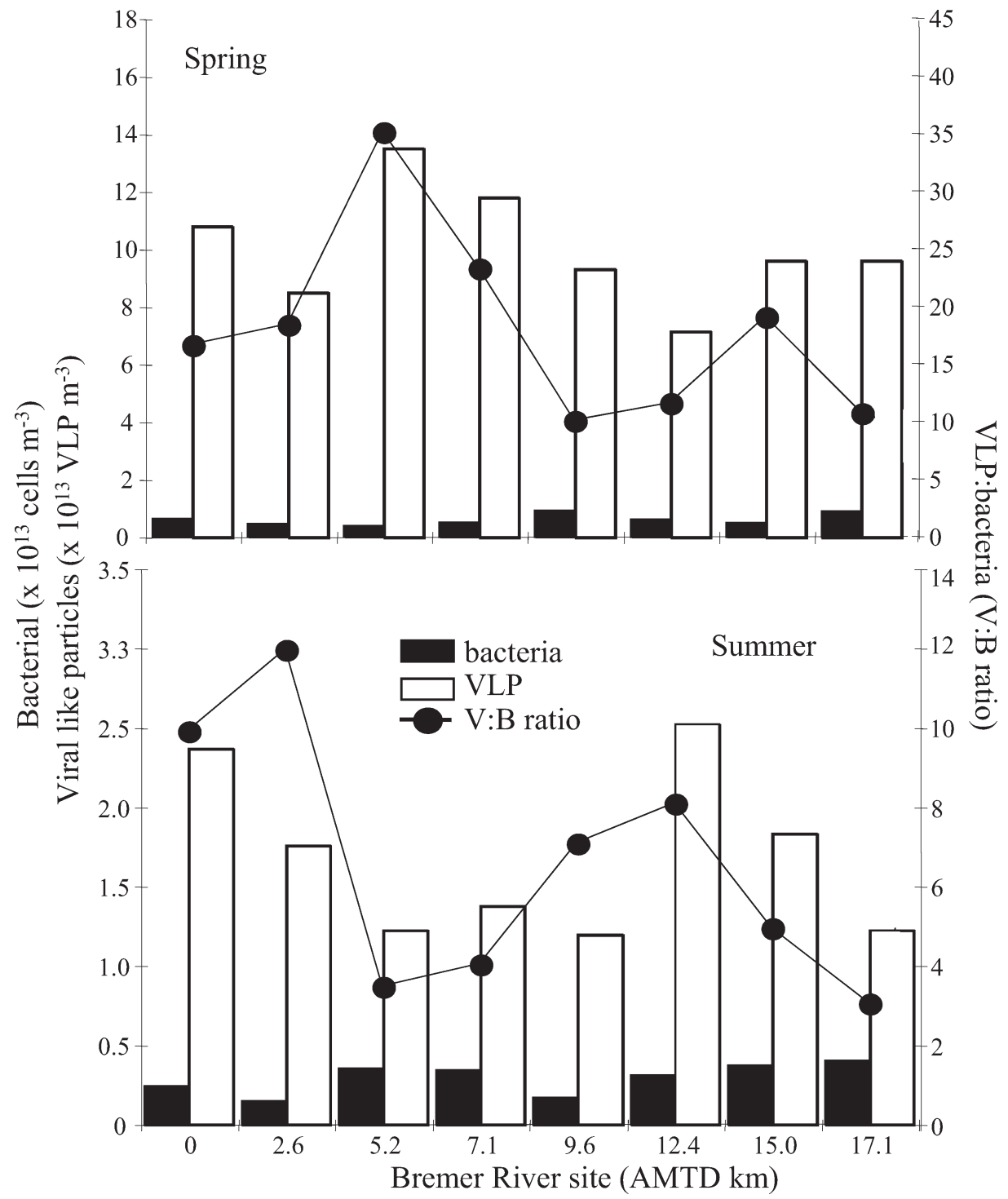

Fig. 5. Bacterial abundance and VLPs. The line shows the trend in the ratio between the two for spring (dry weather) and summer (wet weather).

greater than those measured in marine ecosystems, and our measurements were at least twice those of other eutrophic freshwater ecosystems. Our rates are among the highest recorded for natural tropical aquatic ecosystems. Other freshwater ecosystems were sampled in South East Queensland and confirmed these high rates of bacterial specific growth rates for three freshwater reaches of urban rivers and creeks - the Brisbane and Mary Rivers and Lota Creeks (Table 4; P. C. Pollard unpubl. data).

We estimated the BGE by assuming that most of the measured respiration in the water was bacterial; others that would contribute include algae, plants, protozoans, and invertebrates. This assumption overestimates the actual bacterial respiration and thus provides a conservative estimate of the BGE (Table 5). In the literature, the fraction of the community respiration that bacteria contribute ranges from $11 \%$ to $100 \%$ (Findlay et al. 1992; del Giorgio and Cole 2000; Warkentin et al. 2007). Our measurements and assumptions yielded BGE values of 0.60 and 0.46 for the dry and wet seasons, respectively (Table 3 ). If we assumed that the bacterial respiration was much less than the total measured respiration, the resulting BGE values would be unrealistically high.

In a review of BGE values for aquatic ecosystems, most eutrophic systems plateau near 0.5 (del Giorgio and Cole 1998), consistent with our estimates. Bacterial populations tend to maximize their use of DOC; the energy generated in this process is then allocated between growth and maintenance, depending on the physiological state of the bacteria and the inorganic nutrients available for growth (Pollard et al. 1997). As long as the system is supplied with DOC substrate, the river bacteria continue to respire the DOC. The respiration rate for spring dry weather was lower than the bacterial production, i.e., $\mathrm{BGE}>0.5$ (Table 3). This may have been because bacterial respiration and production were uncoupled, or the critical high initial 
Table 3. Summary of the key parameters measured in this study to quantify the trophic dynamics of the ecosystem of the Bremer River. $\mathrm{BGE}=($ bacterial productivity $) /($ bacterial respiration + bacterial productivity; mean $\pm \mathrm{SE})$.

\begin{tabular}{lcr}
\hline \hline \multicolumn{1}{c}{ Measured parameters } & Spring dry weather $\left(\mathrm{g} \mathrm{C} \mathrm{m}^{-3} \mathrm{~d}^{-1}\right)$ & Summer wet weather $\left(\mathrm{g} \mathrm{C} \mathrm{m}^{-3} \mathrm{~d}^{-1}\right)$ \\
\hline Heterotrophic bacterial productivity & $1.50 \pm 0.20(n=22)$ & $2.6 \pm 0.4(n=8)$ \\
Dissolved organic carbon* & $5.7 \pm 0.3(n=5)$ & $12.6 \pm 1.0(n=8)$ \\
Respiration $\dagger$ & $1.04 \pm 0.12(n=6)$ & $3.2 \pm 0.1(n=6)$ \\
Primary production & $0.10-0.52$ & $0.01-0.045$ \\
Bacterial growth efficiency (BGE)\# & $60 \%$ & $46 \%$ \\
\hline
\end{tabular}

$* \mathrm{~g} \mathrm{C} \mathrm{m}^{-3}$.

$\uparrow$ Calculated from the oxygen uptake rates in the dark.

\#\% bacterial production/(bacterial production + bacterial respiration)

Table 4. Bacterial specific growth rate and productivity in aquatic environments reported in the literature. Freshwater rates were consistently more than 10 times higher than in marine ecosystems.

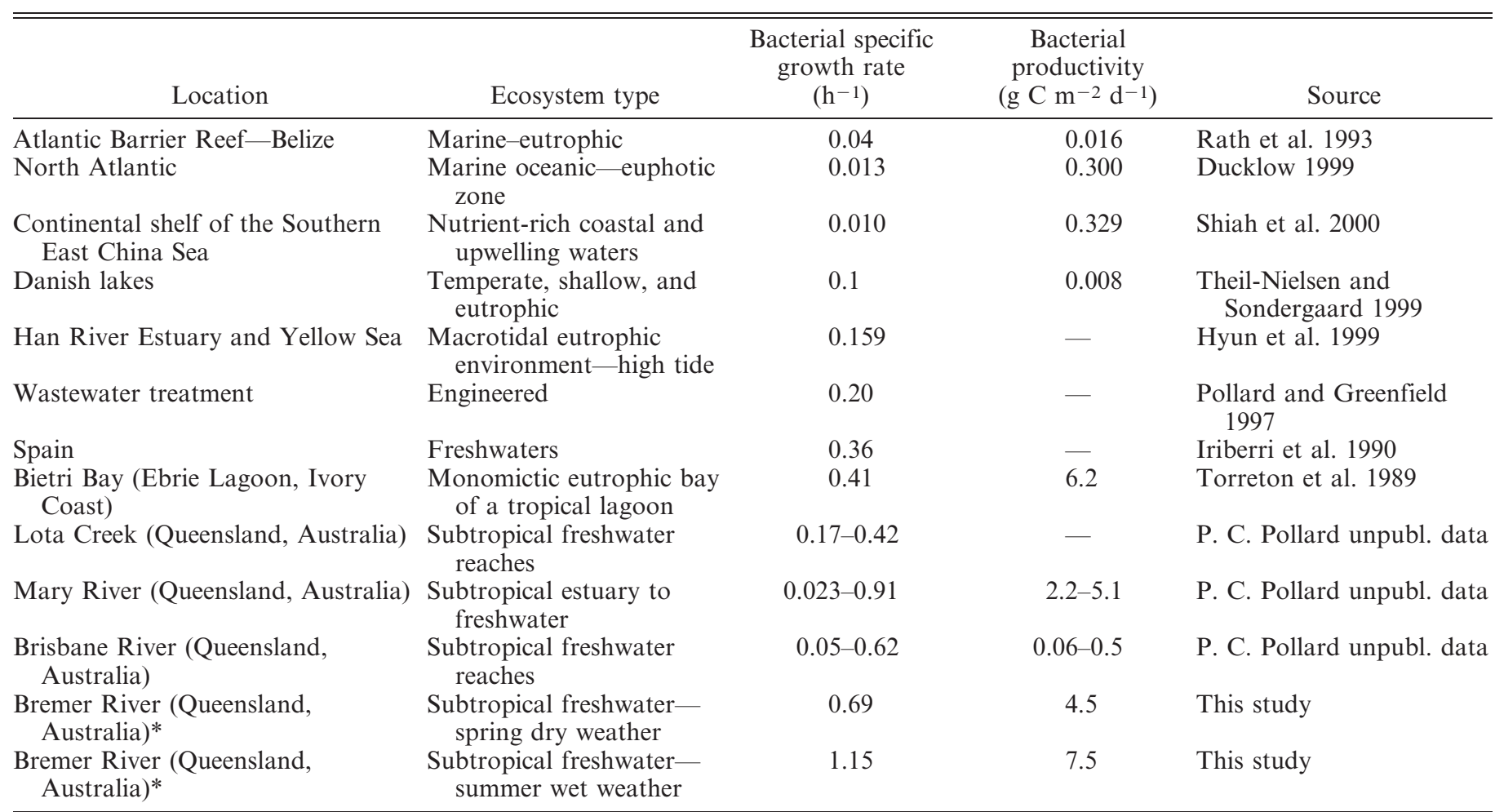

* Mean water depth of $3 \mathrm{~m}$.

Table 5. Comparison of in situ bacterial growth rate efficiencies in estuaries and lakes.

\begin{tabular}{lcl}
\hline \hline \multicolumn{1}{c}{ Site } & Bacterial growth efficiency & \multicolumn{1}{c}{ Source } \\
\hline Bremer River (spring) & 0.60 & This study \\
Bremer River (summer) & 0.46 & This study \\
Florida estuaries & $0.11-0.61$ & Coffin et al. 1993 \\
Hudson River & $0.10-0.50$ & Findlay et al. 1992 \\
Santa Rosa Sound & $0.60-0.61$ & Kroer 1993 \\
Brackish estuary & 0.40 & Laanbroek et al. 1985 \\
Blackwater river & 0.31 & Meyer et al. 1987 \\
Frederiksborg Slotsso & 0.41 & Middelboe and Sondergaard \\
$\quad$ (eutrophic lake) & & 1993 \\
\hline
\end{tabular}




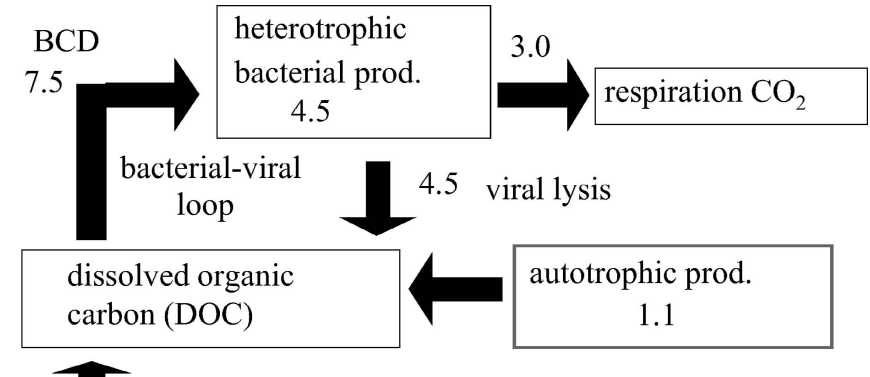

\section{T0.9}

allocthonous
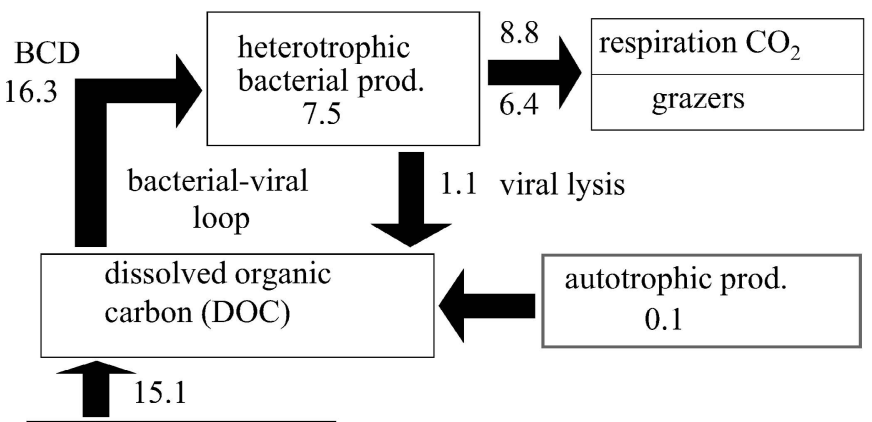

allocthonous

Summer trophic dynamics

Fig. 6. Trophic relationships of the Bremer. The ecosystem was net heterotrophic in spring and summer with primary production (prod.) a minor contributor to the DOC pool that supported bacterial production $(\mathrm{BCD}=$ bacterial carbon demand). All units are $\mathrm{g} \mathrm{C} \mathrm{m}^{-2} \mathrm{~d}^{-1}$. All primary production is assumed to enter the DOC pool over a seasonal time scale in this "best-case" scenario. Allochthonous inputs were adjusted to balance the DOC pool. Average water depth was $3 \mathrm{~m}$.

oxygen decay rate (used to determine respiration) may have been missed because the bacterial respiration and production were so high.

Phytoplankton production and sources of DOC-To help quantitatively distinguish sources of organic carbon to the ecosystem, primary production was also measured and found not to be sufficient to support the high BCD. Benthic microalgae were not considered a major source of primary production, because the euphotic zone was so shallow $(0.75 \mathrm{~m})$. In situ heterotrophic bacterial production dominated over primary production in both wet and dry periods (Fig. 6). In spring dry weather, the heterotrophic bacteria were using DOC at a rate of at least $4.5 \mathrm{~g} \mathrm{C} \mathrm{m}^{-2} \mathrm{~d}^{-1}$ (net bacterial production; Fig. 6) plus the $3.0 \mathrm{~g} \mathrm{C} \mathrm{m}^{-2} \mathrm{~d}^{-1}$ of $\mathrm{CO}_{2}$ that was lost to the atmosphere through respiration using the BGE of $60 \%$. The total BCD was $7.5 \mathrm{~g} \mathrm{C} \mathrm{m}^{-2} \mathrm{~d}^{-1}$. However, on a daily basis, the primary production represented only $15 \%$ of this demand. The pool of DOC in the Bremer River was $6.4 \pm 0.5 \mathrm{mg} \mathrm{L}^{-1}$ (mean $\pm \mathrm{SE}, n=8$ ) and was near a steady state at a concentration consistent with DOC in tropical rivers (Mulholland 2003). DOC was the main fraction of the total pool of organic carbon (Table 2). Based on the rate at which bacteria were using DOC, the water column DOC was turned over every couple of days.
Summer wet weather showed twice as much DOC (12.6 $\pm 1.0 \mathrm{mg} \mathrm{L}^{-1}$; mean $\pm \mathrm{SE}, n=8$ ); however, the rates of primary production were lower than in the dry spring season, while rates of heterotrophic bacterial production were higher. Primary production represented only $1 \%$ of the BCD and, again, could not alone have met the heterotrophic BCD (Fig. 6). In wet weather, twice as much DOC was delivered to the system, and, at the same time, less light was available for photosynthesis based on the PI relationships and PAR measurements in the water column (Table 1; Fig. 3).

In a review of primary and bacterial productivity in the marine environment, Ducklow (1999) found that primary productivity rates ranged from 0.5 to $1.6 \mathrm{~g} \mathrm{C} \mathrm{m}^{-2} \mathrm{~d}^{-1}$. In freshwaters and eutrophic estuaries, the range for primary productivity is higher ( 0.6 to $4 \mathrm{~g} \mathrm{C} \mathrm{m}^{-2} \mathrm{~d}^{-1}$; Rothlisberg et al. 1994; Kromkamp et al. 1995; Cole et al. 2006). We found that in spring dry weather the primary productivity ranged from 0.4 to $1.5 \mathrm{~g} \mathrm{C} \mathrm{m}^{-2} \mathrm{~d}^{-1}$, and in summer wet weather it was much lower, ranging from 0.05 to $0.13 \mathrm{~g} \mathrm{C} \mathrm{m}^{-2} \mathrm{~d}^{-1}$. The subtropical sites in this study were supplying similar amounts of primary production to the ecosystem as temperate freshwater environments, at least in the spring dry climate.

While terrestrial plant DOC is a major source of organic carbon in estuaries (McCallister et al. 2004) and is a major substrate for pelagic bacterial respiration, little of this bacterial carbon passes up the food web (Cole et al. 2006). The higher trophic groups in freshwater depend on primary production (Pace et al. 2004; Davies et al. 2008; Brett et al. 2009), not bacterial production. The results of this study show that phytoplankton production was only a small part of the source of the DOC driving a substantial amount of heterotrophic bacterial production.

Viral abundance and replication - In another study of a tropic freshwater reservoir, others also observed that the dry season was higher than the wet season in terms of viral abundance and was most favorable for viral infection of bacteria (Peduzzi and Schiemer 2004). While our measures of the bacterial specific growth rates were highest in the wet, the viral infection and lysis were lower as indicated by the lower $\mathrm{V}: \mathrm{B}$ ratio, with bacterial mortality due to viral infection and lysis lower during the summer wet season. This conclusion was confirmed using a viral decay rate term, as outlined below.

Viral lysis of heterotrophic bacteria is important to the cycling of organic and inorganic nutrients and is a major cause of bacterial mortality in oligotrophic (Boras et al. 2009) and eutrophic environments (Bongiorni et al. 2005). Heldal and Bratbak (1991) report freshwater viral decay rates of $1.1 \mathrm{~h}^{-1}$ with an average burst size of 50 . Assuming that within a season the abundance of bacteria and viruses remains in a steady state, the following applies:

$$
\begin{aligned}
\mathrm{V} \text { iral specific decay rate } & =\text { viral specific production } \\
& =\mu=1.1 \mathrm{~h}^{-1}=\ln 2 \times \mathrm{t}_{\mathrm{d}}^{-1}
\end{aligned}
$$

With viral abundance remaining constant in the water column, viral specific production $(\mu)$ would be halved every 


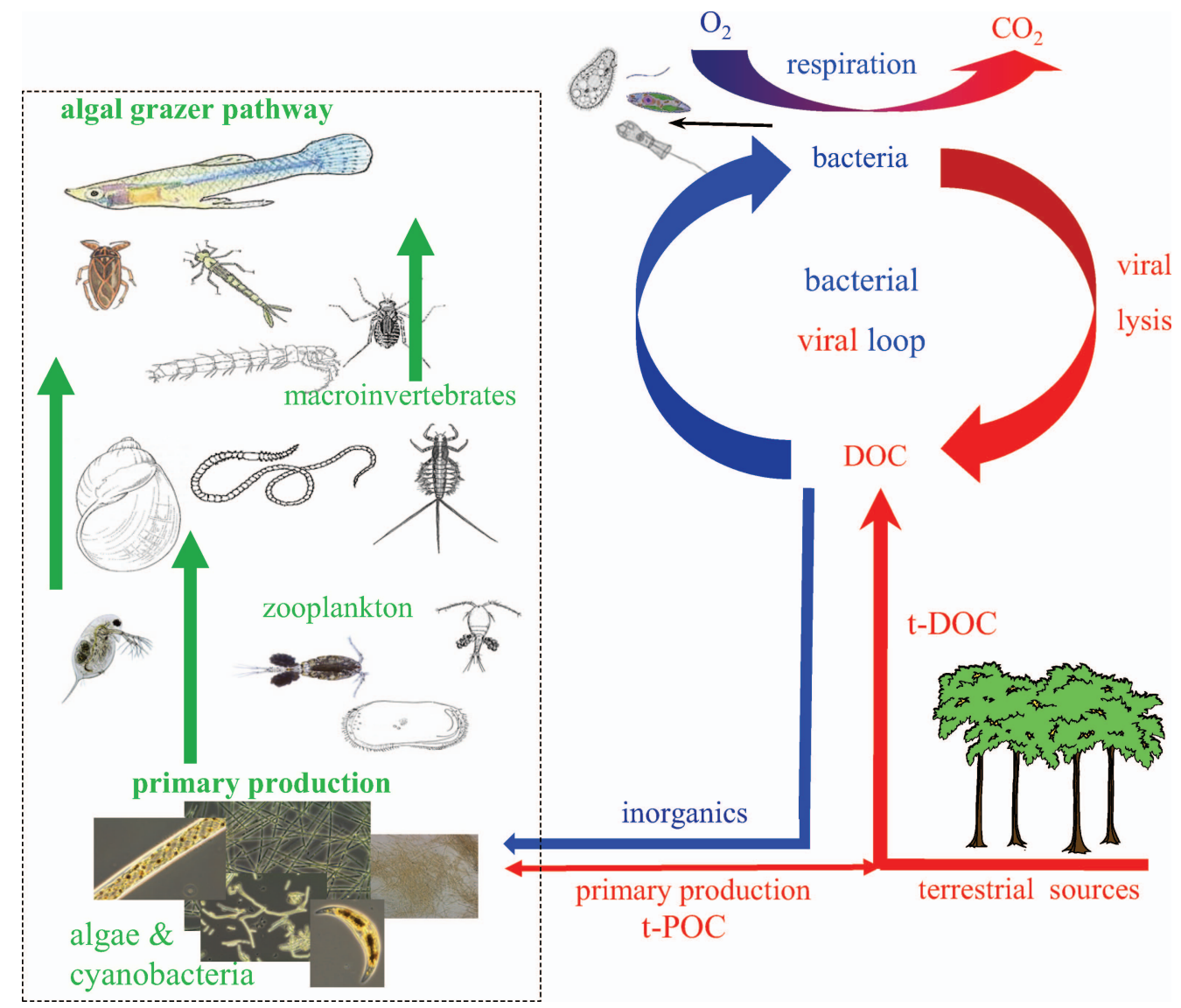

Fig. 7. A bacterial-viral loop prevented bacterial production passing to higher trophic groups. Viral lysis products of new bacterial biomass were passing out of the ecosystem via respiration in this $\mathrm{CO}_{2}$-vented bacterial-viral loop. On each pass of the loop, more DOC was respired as $\mathrm{CO}_{2}$, with the resulting inorganic compounds supporting the algal grazer pathways. Viral infection and lysis of the bacteria expedited the conversion of DOC to $\mathrm{CO}_{2}$. t-DOC and t-POC represent terrestrial DOC and terrestrial particulate organic carbon, respectively.

$0.63 \mathrm{~h}$ (doubling time $=\mathrm{t}_{\mathrm{d}}$ ). In the spring dry season, the mean viral abundance was $10.03 \pm 0.72 \times 10^{10}$ virions $\mathrm{L}^{-1}$ (mean $\pm \mathrm{SE}, n=8$ ), which, divided by 0.63 , would give a viral production value of $17.02 \pm 1.23 \times 10^{10}$ virions $\mathrm{L}^{-1}$ $\mathrm{h}^{-1}$. Division of this value by the burst size of 50 gives a rough estimate of what the bacterial mortality might have been, i.e., $0.34 \pm 0.03 \times 10^{10}$ bacterial cells $\mathrm{L}^{-1} \mathrm{~h}^{-1}$. This bacterial death rate was similar to the rate of bacterial production of $0.29 \pm 0.03 \times 10^{10}$ bacterial cells $\mathrm{L}^{-1} \mathrm{~h}^{-1}$ (mean $\pm \mathrm{SE}, n=8$ ); hypothetically, most, if not all, of the bacterial production was lost through viral lysis. Thus, most bacterial production was lost from the food web ("sink," Ducklow et al. 1986) through viral lysis of bacteria-little of this bacterial production may have passed to higher trophic levels in the spring dry season. This conclusion is consistent with results from the stable isotope research noted above in which primary production is seen as the basis of freshwater food webs, even in the presence of high rates of bacterial production. Several reports also indicate that viral-induced bacterial mortality is similar to that by heterotrophic nanoflagellates (Heldal and Bratbak 1991; Weinbauer 2004; Tanaka et al. 2005).

Using the same viral decay $=$ production rate $\left(1.1 \mathrm{~h}^{-1}\right)$ and burst size (50) for the summer wet season, viral production was possibly five times lower than in the spring dry season $\left(2.7 \pm 0.6 \times 10^{10}\right.$ virions $\mathrm{L}^{-1} \mathrm{~h}^{-1}$; mean $\pm \mathrm{SE}, n$ $=8$ ) that may have been responsible for a bacterial mortality at a rate of $0.05 \pm 0.01 \times 10^{10}$ bacterial cells $\mathrm{L}^{-1} \mathrm{~h}^{-1}$. The bacterial growth rate was $0.36 \pm 0.07 \times 10^{10}$ bacterial cells $\mathrm{L}^{-1} \mathrm{~h}^{-1}$ (mean $\pm \mathrm{SE}, n=8$ ), so only $14 \%$ of bacterial mortality could be attributed to viral lysis of bacteria. Others (Peduzzi and Schiemer 2004; Boras et al. 2009) have shown bacterial mortality ranged from $15 \%$ to $48 \%$ that could be attributed to viruses. Heterotrophic nanoflagellate grazers were possibly responsible for the remaining bacterial mortality. These grazers transfer little bacterial production to higher trophic levels, because several trophic transfers are required to move the bacterial carbon to larger grazers, with respiratory losses at each level (Ducklow et al. 1986).

Ecological consequences of viral lysis of bacteria-Viral lysis of host bacteria generates DOC (Middelboe and Lyck 2002) as seen in Fig. 7. This DOC has been shown to contain remnants of bacteria (McCarthy et al. 1998). Other bacteria consume this lysed bacterial DOC; effectively, bacterial biomass is cannibalized (Nagata 2000). For marine ecosystems, Fuhrman (1999) presented a planktonic 
viral loop showing a semiclosed loop connecting prokaryotes, viruses, and DOC. The net effect of this loop is to convert organic matter into dissolved inorganic nutrients, including respired $\mathrm{CO}_{2}$. Products of viral lysis of bacteria have also been shown to be available to bacteria for growth (Noble et al. 1999). The bacterial-viral loop detours bacterial production away from protists that would otherwise consume the bacteria, returning the biomass to the DOC pool (Fuhrman 1999; Thingstad et al. 2008; Fig. 7).

Figure 6 quantitatively shows the bacterial-viral $\mathrm{CO}_{2}-$ vented loop balancing carbon movement through this ecosystem. The concept (Fig. 7) differs from that of Fuhrman (1999) as it emphasizes the quantitative significance of the trophic loss of organic carbon from the DOC pool via bacterial respiration. The net effect of viral lysis of the bacteria is to oxidize organic material and regenerate inorganic nutrients that support primary production (Haaber and Middelboe 2009). New bacterial biomass coming from the products of viral lysis of other bacteria continues to respire $\mathrm{CO}_{2}$ in the $\mathrm{CO}_{2}$-vented bacterial-viral loop (Fig. 7). On each pass of the loop, more DOC would be respired as $\mathrm{CO}_{2}$; the DOC is continuously passing out of this loop as $\mathrm{CO}_{2}$. Thus little bacterial carbon is passing to higher trophic levels.

In our study (Figs. 6, 7), the DOC pool remained relatively constant within a season despite the high $\mathrm{BCD}$. This suggests that there was a continuous supply of terrestrial DOC to support the high bacterial production. Understandably, this source was greatest in wet weather, when runoff would bring much organic carbon into the river from the catchment. On the other hand, in the dry weather less carbon came from the catchment, but much more DOC was being recycled through viral lysis of bacteria. In the absence of sufficient primary production to support all the $\mathrm{BCD}$, terrestrial $\mathrm{DOC}$ was likely returned to the atmosphere as $\mathrm{CO}_{2}$ gas emissions through bacterial respiration (Cole et al. 2000, 2006) assisted by viral infection and lysis of the bacteria, while phytoplankton sustained the higher trophic groups (Brett et al. 2009).

The subtropical Australian Bremer River was net heterotrophic in dry and wet weather. We demonstrated that the net heterotrophic condition was the result of very high bacterial production and respiration. Further, we demonstrated that primary production was not sufficient to support the high $\mathrm{BCD}$. The work showed that the relatively constant concentrations of DOC (within a season) turned over within days; the abundance of bacteria and viruses accompanied some of the highest rates of bacterial production seen in natural freshwater ecosystems, with trends in high specific bacterial growth rates accompanying $\mathrm{V}: \mathrm{B}$ ratio trends. Viral-induced bacterial mortality likely consumed most of the new bacterial production in the dry spring season. Bacterial metabolic processes appeared to be removing a continuous supply of terrestrial DOC through the viral lysis of the bacterial biomass that augmented bacterial respiration. The net effect of viral lysis of the bacteria was to oxidize more dissolved organic material and regenerate inorganic nutrients to support primary production. New bacterial biomass coming from the products of viral lysis of bacteria continued to respire DOC in a $\mathrm{CO}_{2}$ vented bacterial-viral loop. On each pass of the loop, more DOC was respired as $\mathrm{CO}_{2}$ and was lost from the ecosystem. These subtropical freshwater ecosystems of Australia appear to contribute a disproportionately large amount of $\mathrm{CO}_{2}$ to the global carbon cycle. To answer the question in the title, yes - viral lysis can short-circuit the microbial loop.

\section{Acknowledgments}

This research is dedicated to the memory of Dr. Christy Fellows, a devoted, passionate, and talented young scientist. Thanks go to the Coastal Cooperative Research Centre and the Healthy Waterways Partnership for their funding and the help of Melissa Wos, Steve Tucker, Heather Uwins, Milani Chaloupka, Roger Shaw, and the Environmental Protection Agency boating staff; without them this work could not have achieved so much. Thank you, Ann Chuang and Loretta Young, for the algal and cyanobacterial pictures. The valuable input of the anonymous reviewers was also most appreciated.

\section{References}

Abedon, S. T. 2008. Bacteriophage ecology: Population growth, evolution, and impact of bacterial viruses. Cambridge Univ. Press.

Acuna, V., A. Wolf, U. Uehlinger, and K. Tockner. 2008. Temperature dependence of stream benthic respiration in an Alpine river network under global warming. Freshw. Biol. 53: 2076-2088, doi:10.1111/j.1365-2427.2008. 02028.x

Azam, F., T. Fenchel, J. G. Field, L. A. Meyer-Reil, and F. Thingstadt. 1983. The ecological role of water column microbes in the sea. Mar. Ecol. Prog. Ser. 10: 257-263, doi:10.3354/meps010257

Bell, R. T. 1993. Estimating production of heterotrophic bacterioplankton via incorporation of tritiated thymidine, $\mathrm{p}$. 495-504. In P. F. Kemp, B. F. Sherr, E. B. Sherr, and J. J. Cole [eds.], Handbook of methods in aquatic microbial ecology. Lewis.

Bloem, J., M. Veninga, And J. Shepherd. 1995. Fully automatic determination of soil bacterium numbers, cell volumes, and frequencies of dividing cells by confocal laser scanning microscopy and image analysis. Appl. Environ. Microbiol. 61: 926-936.

Bongiorni, L., M. Magagnini, M. Armeni, R. Noble, and R. DANOvaro. 2005. Viral production, decay rates, and life strategies along a trophic gradient in the North Adriatic Sea. Appl. Environ. Microbiol. 71: 6644-6650, doi:10.1128/ AEM.71.11.6644-6650.2005

Bonilla-Findi, O., A. Malits, D. Lefèvre, E. J. RochelleNewall, E. R. Lemée, M. G. Weinbauer, and J.-P. Gattuso. 2008. Viral effects on bacterial respiration, production and growth efficiency: Consistent trends in the Southern Ocean and the Mediterranean Sea. Deep-Sea Res. II 55: 790-800, doi:10.1016/j.dsr2.2007.12.004

Boras, J. A., M. M. Sala, E. Vazquez-Dominguez, M. G. Weinbauer, And D. Vaque. 2009. Annual changes of bacterial mortality due to viruses and protists in an oligotrophic coastal environment (NW Mediterranean). Environ. Microbiol. 11: 1181-1193, doi:10.1111/j.1462-2920.2008.01849.x

Brett, M. T., M. J. Kainz, S. J. Taipale, and H. Seshan. 2009. Phytoplankton, not allochthonous carbon, sustains herbivorous zooplankton production. Proc. Natl. Acad. Sci. USA 106: 21197-21201, doi:10.1073/pnas.0904129106 
Bunn, S., P. M. Davies, And M. Winning. 2003. Sources of organic carbon supporting the food web of an arid zone floodplain river. Freshw. Biol. 41: 619-635, doi:10.1046/ j.1365-2427.2003.01031.x

Bunn, S. E., S. R. Balcombe, P. M. Davies, C. S. Fellows, and F. J. Mckenzie-Smith. 2006. Productivity and aquatic food webs of desert river ecosystems, p. 76-99. In R. T. Kingsford [ed.], Changeable, changed, changing: The ecology of desert rivers. Cambridge Univ. Press.

Caraco, N. F., J. E. Bauer, J. J. Cole, S. Petsch, and P. A. RAYMOND. 2010. Millennial aged organic carbon subsidies to a modern river food web. Ecology 91: 2381-2389, doi:10.1890/ 09-0330.1

Chróst, R. J., J. Overbeck, And R. Wcislo. 1988. Evaluation of the $\left[{ }^{3} \mathrm{H}\right]$ thymidine method for estimating bacterial growth rates and production in lake water: Reexamination and methodological comments. Acta Microbiol. Pol. 37: 95-112.

Clapcott, J. E., and S. E. Bunn. 2003. Can $\mathrm{C}_{4}$ plants contribute to aquatic food webs of subtropical streams? Freshw. Biol. 48: 1105-1116, doi:10.1046/j.1365-2427.2003.01077.x

Coffin, R. B., J. P. Connolly, and P. S. Harris. 1993. Availability of dissolved organic carbon to bacterioplankton examined by oxygen utilisation. Mar. Ecol. Prog. Ser. 101: 9-22, doi:10.3354/meps 101009

Cole, J. J., and N. F. Caraco. 2001. Carbon in catchments connecting terrestrial carbon losses with aquatic metabolism. Mar. Freshw. Res. 52: 101-110, doi:10.1071/MF00084

S. R. Carpenter, M. L. Pace, M. C. Van de Bogert, J. L. Kitchell, And J. R. Hodgson. 2006. Differential support of lake food webs by three types of terrestrial organic carbon. Ecol. Lett. 9: 558-568, doi:10.1111/j.1461-0248. 2006.00898.x

—, M. L. Pace, S. R. Carpenter, and J. F. Kitchell. 2000. Persistence of net heterotrophy in lakes during nutrient addition and food web manipulations. Limnol. Oceanogr. 45: 1718-1730, doi:10.4319/1o.2000.45.8.1718

- AND OTHERS. 2007. Plumbing the global carbon cycle: Integrating inland waters into the terrestrial carbon budget. Ecosystems 10: 171-184, doi:10.1007/s10021-006-9013-8

Davies, P., S. BunN, and S. Hamilton. 2008. Primary production in tropical streams and rivers, p. 23-42. In D. Dudgeon [ed.], Aquatic ecosystems: Tropical stream ecology. Elsevier Science.

del Giorgio, P. A., And J. J. Cole. 1998. Bacterial growth efficiency in natural aquatic systems. Annu. Rev. Ecol. Syst. 29: 503-541, doi:10.1146/annurev.ecolsys.29.1.503

- AND . 2000. Bacterial energetics and growth efficiencies, p. 289-325. In D. L. Kirchman [ed.], Microbial ecology of the oceans. Wiley-Liss.

- AND P. J. Williams. 2005. Respiration in aquatic ecosystems. Oxford Univ. Press.

Ducklow, H. W. 1999. The bacterial component of the oceanic euphotic zone. FEMS Microbiol. Ecol. 30: 1-10, doi:10.1111/ j.1574-6941.1999.tb00630.x

2000. Bacterial production and biomass in the oceans, p. 85-120. In D. L. Kirchman [ed.], Microbial ecology of the oceans. Wiley-Liss.

, D. A. Purdie, P. J. L. Williams, And J. M. Davies. 1986. Bacterioplankton: A sink for carbon in a coastal marine plankton community. Science 232: 865-867, doi:10.1126/science.232. 4752.865

Eilers, P. H. C., And J. C. H. Peeters. 1988. A model for the relationship between light intensities and the rate of photosynthesis in phytoplankton. Ecol. Model. 42: 199-215, doi:10.1016/0304-3800(88)90057-9
Farjalla, V. F., A. M. Amado, A. L. Suhett, and F. MeirelleesPereira. 2009a. DOC removal paradigms in highly humic aquatic ecosystems. Environ. Sci. Pollut. Res. 16: 531-538, doi:10.1007/s11356-009-0165-X

, C. C. Marinho, B. M. Faria, A. M. Amado, F. de A. Esteves, R. L. Bozelli, And D. Giroldo. 2009b. Synergy of fresh and accumulated organic matter to bacterial growth. Microb. Ecol. 57: 657-666, doi:10.1007/s00248-008-9466-8

Findlay, S., M. L. Pace, D. Lints, and K. Howe. 1992. Bacterial metabolism of organic carbon in the tidal freshwater Hudson Estuary. Mar. Ecol. Prog. Ser. 89: 147-153, doi:10.3354/ meps089147

- R. L. Sinsabaugh, D. T. Fischer, and P. Franchini. 1998. Sources of dissolved organic carbon supporting planktonic bacterial production in the tidal freshwater Hudson River. Ecosystems 1: 227-239, doi:10.1007/ s100219900018

Fuhrman, J. A. 1999. Marine viruses and their biogeochemical and ecological effects. Nature 399: 541-548, doi:10.1038/ 21119

- AND F. AzAm. 1982. Thymidine incorporation as a measure of heterotrophic bacterioplankton production in marine surface waters: Evaluation and field results. Mar. Biol. 66: 109-120, doi:10.1007/BF00397184

Greenwood, J., AND others. 1999. Brisbane River and Moreton Bay wastewater management study: Plankton trophic dynamics. School of Marine Science, The University of Queensland, Australia.

HaAber, J., And M. Middelboe. 2009. Viral lysis of Phaeocystis pouchetii: Implications for algal population dynamics and heterotrophic C, $\mathrm{N}$ and $\mathrm{P}$ cycling. ISME J. 3: 430-441, doi:10.1038/ismej.2008.125

Heldal, M., and G. Bratbak. 1991. Production and decay of viruses in aquatic environments. Mar. Ecol. Prog. Ser. 72: 205-212, doi:10.3354/meps072205

Hewson, I., J. M. O’Neil, J. A. Fuhrman, and W. C. Dennison. 2001. Virus-like particle distribution and abundance in sediments and overlying waters along eutrophication gradients in two subtropical estuaries. Limnol. Oceanogr. 46: 1734-1746, doi:10.4319/1o.2001.46.7.1734

Hyun, J. H., J. K. Choi, K. H. Chung, E. J. Yang, and M. K. KIM. 1999. Tidally induced changes in bacterial growth and viability in the macro-tidal Han River estuary, Yellow Sea. Estuar. Coast. Shelf Sci. 48: 143-153, doi:10.1006/ ecss.1998.0421

Iriberri, J., M. Unanue, B. Ayo, I. Barcina, and L. Egea. 1990 Bacterial production and growth rate estimation from $\left[{ }^{3} \mathrm{H}\right]-$ thymidine incorporation for attached and free-living bacteria in aquatic systems. Appl. Environ. Microbiol. 56: 483-487.

Johnson, M. S., J. Lehmann, S. J. Riha, A. V. Krusche, J. E. Richey, J.P.H.B. Ometto, and E. G. Couto. 2008. $\mathrm{CO}_{2}$ efflux from Amazonian headwater streams represents a significant fate for deep soil respiration. Geophys. Res. Lett. 35: 1-5, L17401, doi:10.1029/2008GL034619

Koeve, W., and H. W. Ducklow. 2001. JGOFS research in the North Atlantic Ocean: A decade of research, synthesis and modeling. Deep-Sea Res. II 48: 2141-2424, doi:10.1016/ S0967-0645(00)00186-7

Kroer, N. 1993. Bacterial growth efficiencies on natural dissolved organic matter. Limnol. Oceanogr. 38: 1282-1290, doi:10.4319/lo.1993.38.6.1282

Kromkamp, J., J. Peene, P. van Rijswijk, A. Sandee, and N. Goosen. 1995. Nutrients, light and primary production by phytoplankton and micro-phytobenthos in eutrophic, turbid Westerschelde estuary (The Netherlands). Hydrobiologica 311: 9-19, doi:10.1007/BF00008567 
Laanbroek, H. J., J. C. Verplankc, P. R. M. de Visscher, and R. DE VUYST. 1985. Distribution of phytoplankton and bacterioplankton growth and biomass parameters dissolved inorganic nutrients and free amino acids during a spring bloom in the Oosterschelde basin, The Netherlands. Mar. Ecol. Prog. Ser. 25: $1-12$, doi: $10.3354 /$ meps025001

Marotta, H., C. M. Duarte, S. Sobek, and A. Enrich-Prast. 2009. Large $\mathrm{CO}_{2}$ disequilibria in tropical lakes. Global Biogeochem. Cycles 23: GB4022, doi:10.1029/2008GB003434

MAYORGA, E., AND OTHERs. 2005. Young organic matter as a source of carbon dioxide outgassing from Amazonian rivers. Nature 436: 538-541, doi:10.1038/nature 03880

McCallister, S. L., J. E. Bauer, J. E. Cherrier, and H. W. DuckLow. 2004. Assessing sources and ages of organic matter supporting river and estuarine bacterial production: A multiple-isotope $\left(\delta^{14} \mathrm{C}, \delta{ }^{13} \mathrm{C}\right.$, and $\left.\delta{ }^{15} \mathrm{~N}\right)$ approach. Limnol. Oceanogr. 49: 1687-1702, doi:10.4319/1o.2004.49.5.1687

McCarthy, M. D., J. I. Hedges, and R. Benner. 1998. Major bacterial contributions to marine dissolved organic nitrogen. Science 28: 231-234, doi:10.1126/science.281.5374.231

Meyer, J. L. 1994. The microbial loop in flowing waters. Microb. Ecol. 28: 195-199, doi:10.1007/BF00166808

- R. T. EDWARDS, AND R. Risley. 1987. Bacterial growth on dissolved organic carbon from a blackwater river. Microb. Ecol. 13: 13-30, doi:10.1007/BF02014960

Middelboe, M., AND P. G. Lyck. 2002. Regeneration of dissolved organic matter by viral lysis in marine microbial communities. Aquat. Microb. Ecol. 27: 187-194, doi:10.3354/ame027187

, AND M. SondergaARd. 1993. Bacterioplankton growth yield: Seasonal variations and coupling to substrate lability and beta-glucosidase activity. Appl. Environ. Microbiol. 59: 3916-3921.

Mulholland, P. J. 2003. Large-scale patterns in dissolved organic carbon concentrations, flux, and sources, p. 139-159. In S. E. G. Findlay and R. L. Sinsabaugh [eds.], Aquatic ecosystems: Interactivity of dissolved organic matter. Academic.

Muylaert, K., R. Dasseville, L. De Brabandere, F. Dehairs, and W. Vyverman. 2005. Dissolved organic carbon in the freshwater tidal reaches of the Schelde estuary. Estuar. Coast. Shelf Sci. 64: 591-600, doi:10.1016/j.ecss.2005.04.010

Nagata, T. 2000. Production mechanisms of dissolved organic matter, p. 121-152. In D. L. Kirchman [ed.], Microbial ecology of the oceans. Wiley.

Noble, R. T., And J. A. Fuhrman. 1998. Use of SYBR Green I for rapid epifluorescence counts of marine viruses and bacteria. Aquat. Microb. Ecol. 14: 113-118, doi:10.3354/ame014113

, M. Middelboe, and J. A. Fuhrman. 1999. Effects of viral enrichment on the mortality and growth of heterotrophic bacterioplankton. Aquat. Microb. Ecol. 18: 1-13, doi:10.3354/ame018001

PACE, M. L., AND others. 2004. Whole lake carbon-13 additions reveal terrestrial support of aquatic food webs. Nature 427: 240-243, doi:10.1038/nature02227

Peduzzi, P., And F. Schiemer. 2004. Bacteria and viruses in the water column of tropical freshwater reservoirs. Environ. Microbiol. 6: 707-715, doi:10.1111/j.1462-2920.2004.00602.x

Pollard, P. C. 2007. How viruses control microbial ecosystems. Microbiol. Aust. 28: 115-117.

— AND P. F. GReENFIELD. 1997. Measuring in situ bacterial specific growth rates $(\mu)$ and population dynamics in wastewater. Water Res. 31: 1074-1082, doi:10.1016/S00431354(96)00326-0

—, And K. Kogure. 1993. The role of epiphytic and epibenthic algal productivity in a tropical seagrass, Syringodium isoetifolium, (Aschers.) Dandy, community. Aust. J. Mar. Freshw. Res. 44: 141-154.
, And D. J. W. Moriarty. 1984. Validity of the tritiated thymidine method for estimating bacterial growth rates: Measurement of isotope dilution during DNA synthesis. Appl. Environ. Microbiol. 48: 1076-1083.

- M. A. Steffens, C. A. Biggs, and P. A. Lant. 1997. Bacterial growth dynamics in activated sludge batch assays. Water Res. 32: 587-596, doi:10.1016/S0043-1354(97)00303-5

-, AND OTHERs. 2001. Bremer River study-estuarine ecological processes. Coastal Zone CRC for the South East Queensland Regional Water Quality Management Strategy, Brisbane, Australia.

Rath, J., C. Schiller, and J. Hernd. 1993. Ectoenzymatic activity and bacterial dynamics along a trophic gradient in the Caribbean Sea. Mar. Ecol. Prog. Ser. 102: 89-96, doi:10.3354/ meps 102089

Richey, J. E., J. M. Melack, A. K. Aufdenkampe, V. M. Ballester, And L. L. Hess. 2002. Outgassing from Amazonian rivers and wetlands as a large tropical source of atmospheric $\mathrm{CO}_{2}$. Nature 416: 617-620, doi:10.1038/416617a

Rohwer, F., And R. V. Thurber. 2009. Viruses manipulate the marine environment. Nature 459: 207-212, doi:10.1038/ nature 08060

Rothlisberg, P. C., P. C. Pollard, P. D. Nichols, D. J. W. Moriarty, A. M. G. Forbes, C. J. Jackson, and D. Vaudrey. 1994. Phytoplankton community structure and productivity in relation to the hydrological regime of the Gulf of Carpentaria, Australia, in summer. Aust. J. Mar. Freshw. Res. 45: 265-282, doi:10.1071/MF9940265

Sherr, E., AND B. Sherr. 1988. Role of microbes in pelagic food webs: A revised concept. Limnol. Oceanogr. 33: 1225-1227, doi:10.4319/lo.1988.33.5.1225

Shiah, F.-K., K.-K. LiU, And G. C. Gong. 2000. The coupling of bacterial production and hydrography in the southern East China Sea: Spatial patterns in spring and fall. Cont. Shelf Res. 20: 459-477, doi:10.1016/S0278-4343(99)00081-3

Sinsabaugh, R. L., And S. Findlay. 2003. Dissolved organic matter: Out of the black box and into the mainstream, $p$. 479-498. In S. E. G. Findlay and R. L. Sinsabaugh [eds.], Aquatic ecosystems: Interactivity of dissolved organic matter. Academic/Elsevier.

Sobczak, W. V., J. E. Cloern, A. D. Jassby, B. E. Cole, T. S. Schraga, And A. Arnsberg. 2005. Detritus fuels ecosystem metabolism but not metazoan food webs in San Francisco estuary's freshwater delta. Estuaries 28: 122-135, doi:10.1007/ BF02732759

- AND S. Findlay. 2002. Variation in bioavailability of dissolved organic carbon among stream hyporheic flowpaths. Ecology 83: 3194-3209, doi:10.1890/0012-9658(2002)083 [3194:VIBODO]2.0.CO;2

Sobek, S., L. J. Tranvik, and J. J. Cole. 2005. Temperature independence of carbon dioxide supersaturation in global lakes. Glob. Biogeochem. Cycles 19: 1-10, doi:10.1029/ 2004GB002264

- Y. T. Prairie, P. Kortelainen, and J. J. Cole. 2007. Patterns and regulation of dissolved organic carbon: An analysis of 7,500 widely distributed lakes. Limnol. Oceanogr. 52: 1208-1219, doi:10.4319/lo.2007.52.3.1208

Strickland, J. D. H., and T. R. Parsons. 1968. A practical handbook of seawater analysis. Bull. Fish. Res. Bd. Canada, 167.

Suttle, C. 2005. Viruses in the sea. Nature 437: 356-361, doi: $10.1038 /$ nature 04160

Tanaka, T., F. Rassoulzadegan, and T. F. Thingstad. 2005. Analyzing the trophic link between the mesopelagic microbial loop and zooplankton from observed depth profiles of bacteria and protozoa. Biogeosciences 2: 9-13, doi:10.5194/ bg-2-9-2005 
Theil-Nielsen, J., AND M. SondergaArd. 1999. Production of epiphytic bacteria and bacterioplankton in three shallow lakes. OIKOS 86: 283-292, doi:10.2307/3546446

Thingstad, T. F., G. Bratbak, and M. Heldal. 2008. Aquatic phage ecology, p. 251-280. In S. T. Abedon [ed.], Bacteriophage ecology. Cambridge Univ. Press.

ThORP, J. H. 2002. Dominance of autochthonous autotrophic carbon in food webs of heterotrophic rivers. OIKOS 93: 543-550, doi:10.1034/j.1600-0706.2002.960315.x

Torreton, J.-P., D. Guiral, AND R. Arfi. 1989. Bacterioplankton biomass and production during destratification in a monomictic eutrophic bay of atropical lagoon. Mar. Ecol. Prog. Ser. 57: 53-67, doi:10.3354/meps057053

von Münch, E., AND P. C. Pollard. 1997. Measuring bacterial biomass-cod in wastewater containing particulate matter. Water Res. 31: 2550-2556, doi:10.1016/S0043-1354(97)00089-4

Warkentin, M., H. M. Freese, U. Karsten, and R. Schumann. 2007. New and fast method to quantify respiration rates of bacterial and plankton communities in freshwater ecosystems by using optical oxygen sensor spots. Appl. Environ. Microbiol. 73: 6722-6729, doi:10.1128/AEM.00405-07
Weinbauer, M. G. 2004. Ecology of prokaryotic viruses. FEMS Microbiol. Rev. 28: 127-181, doi:10.1016/j.femsre. 2003.08.001

, K. Hornak, J. Jezbera, J. Nedoma, J. R. Dolan, and K. SimeK. 2007. Synergistic and antagonistic effects of viral lysis and protistan grazing on bacterial biomass, production and diversity. Environ. Microbiol. 9: 777-788, doi:10.1111/j.14622920.2006.01200.x
Associate editor: Wade H. Jeffrey

Received: 26 October 2010 Accepted: 05 February 2011 Amended: 16 February 2011 